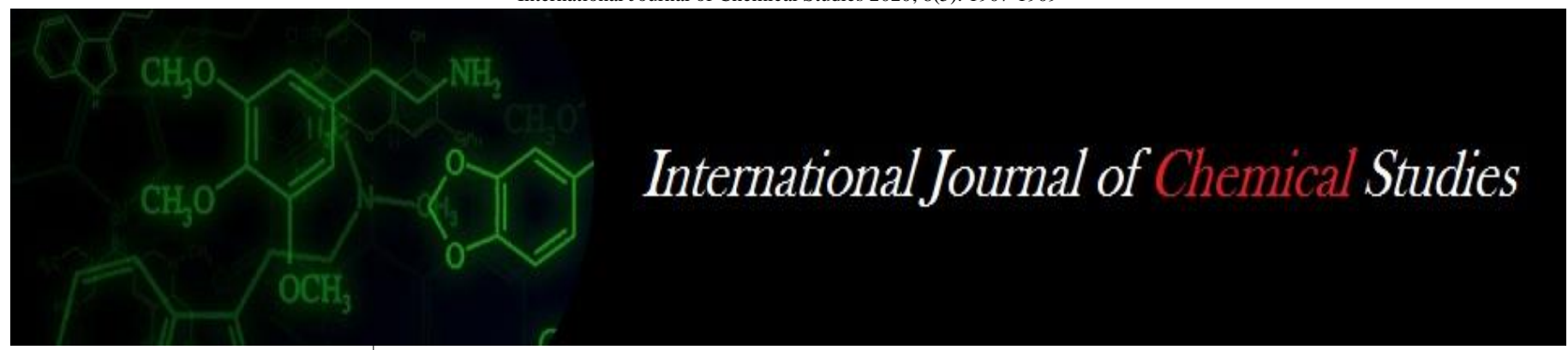

P-ISSN: 2349-8528

E-ISSN: 2321-4902

www.chemijournal.com

IJCS 2020; 8(5): 1907-1909

(C) 2020 IJCS

Received: 15-07-2020

Accepted: 19-08-2020

\section{N Anuradha}

Acharya NG. Ranga Agricultural

University, Agricultural

Research Station, Vizianagaram,

Andhra Pradesh, India

\section{TSSK Patro}

Acharya NG. Ranga Agricultural University, Agricultural

Research Station, Vizianagaram,

Andhra Pradesh, India

U Triveni

Acharya NG. Ranga Agricultural University, Agricultural

Research Station, Vizianagaram, Andhra Pradesh, India

\section{P Joga Rao}

Acharya NG. Ranga Agricultural University, Agricultural

Research Station, Vizianagaram,

Andhra Pradesh, India

\section{Y Sandhya Rani}

Acharya NG. Ranga Agricultural

University, Agricultural

Research Station, Vizianagaram,

Andhra Pradesh, India

\section{P Kranthi Priya}

Acharya NG. Ranga Agricultural University, Agricultural

Research Station, Vizianagaram,

Andhra Pradesh, India
Corresponding Author:

\section{N Anuradha}

Acharya NG. Ranga Agricultural University, Agricultural

Research Station, Vizianagaram, Andhra Pradesh, India

\section{Assessment of genetic variability estimates in Kodo millet Paspalum scrobiculatum (L.)}

\author{
N Anuradha, TSSK Patro, U Triveni, P Joga Rao, Y Sandhya Rani and P \\ Kranthi Priya
}

DOI: https://doi.org/10.22271/chemi.2020.v8.i5z.10582

\begin{abstract}
Kodo millet (Paspalum scrobiculatum L.) genotypes were evaluated at Agricultural Research Station, Vizianagaram to assess genetic variability, heritability and genetic advance for six yield contributing traits. The ANOVA revealed significant differences among eighteen genotypes for all the characters included under study except plant height, number of productive tillers per plant and fodder yield. Moderate PCV was recorded for fodder yield followed by grain yield and plant height whereas the GCV for all the characters were low compared to PCV indicating the interaction of genotypes with the environment. High heritability was recorded for days to maturity and days to $50 \%$ flowering. The maximum genetic advance as percent of mean was observed for days to $50 \%$ flowering followed by days to maturity. High heritability coupled with moderate genetic advance as percent of mean was recorded for days to $50 \%$ flowering indicating that these traits are under influence of both additive and nonadditive gene action and selection may be effective for this trait. Grain yield per plant recorded moderate heritability with moderate genetic advance as percent mean which also indicates presence of both additive gene action and this trait was found to be significantly and positively correlated with days to $50 \%$ flowering, days to maturity and fodder yield. Indirect selection for days to $50 \%$ flowering may help in better advancement for grain yield as flowering is supposed to be controlled by fewer genes with major effect compared to grain yield. The above yield components also exhibited positive intercorrelation among themselves.
\end{abstract}

Keywords: Assessment, genetic variability, Paspalum scrobiculatum L.

\section{Introduction}

Kodo millet (Paspalum scrobiculatum $\mathrm{L})(2 \mathrm{n}=4 \mathrm{x}=40)$ is an indigenous cereal crop of India and it is widely distributed in tropics and sub tropics of the world. It is a traditional, long duration and drought resistant crop mainly grown for its grain and fodder. It ranks second in area and production after finger millet in India and occupies an area of 152.5 thousand hectares with production and productivity of 41.2 thousand tonnes and $312 \mathrm{~kg} / \mathrm{ha}$ respectively (Padulosi et al., 2009) ${ }^{[6]}$. The crop reaches to maturity within 3-4 months and yields ranging from 250$1000 \mathrm{~kg} / \mathrm{ha}$ with 1000 Kernal weight of $6.7 \mathrm{~g}$ (Hulse et al., 1980) ${ }^{[3]}$. The seed spossesses excellent storage life and can be stored for many years.

Because of this reason, Kodo millet is known as the famine grain in many parts of the country. It is having high anti-oxidant property (anticancer) when compared to other millets (Chandrasekara and Shahidi, 2011) ${ }^{[2]}$.

For any crop improvement programme knowing about genetic variability among the population is a prerequisite. Genetic improvement through traditional breeding approaches depends mainly on the availability of diverse germplasm and the presence of variability. An insight into the nature and magnitude of genetic variability present in the gene pool is of immense value for starting any systematic breeding programme because the presence of considerable genetic variability in the base material ensures better chances of evolving desirable plant type.

Hence, an attempt was made to estimate the extent of variation for yield contributing traits in the germplasm accessions by studying PCV, GCV, Heritability and Genetic advance which may provide suitable selection indices for improvement of the crop. 


\section{Material and Methods}

Eighteen genotypes of Kodo millet were evaluated at Agriculture Research Station, Vizianagaram. The experiment was laid out in Randomized Block Design with three replications with a spacing of $22.5 \mathrm{~cm} \times 7.5 \mathrm{~cm}$ during kharif, 2019. All the recommended agronomic practices and plant protection measures were adopted. Data was collected on six quantitative traits like days to $50 \%$ flowering, plant height, days to maturity, number of productive tillers per plant, grain yield and fodder yield per plant.

The mean of all the plants for each trait under each replication was subjected to ANOVA as per the method suggested by (Panse and Sukhathme, 1967) ${ }^{[7]}$. The estimates of GCV and PCV were worked out according to the method suggested by (Burton, 1952) ${ }^{[1]}$. Heritability in broad sense was calculated as per the formula given by (Lush, 1940) ${ }^{[5]}$. Range of heritability was categorized as suggested by (Robinson et al., 1949) ${ }^{[8]}$. Genetic advance was estimated according to the method suggested by (Johnson et al., 1955) ${ }^{[4]}$. Correlations were calculated as suggested by (Johnson et al., 1955) ${ }^{[4]}$.

\section{Results and Discussion}

Analysis of variance showed significant differences among the genotypes for all the characters included under study except plant height, number of productive tillers per plant and fodder yield (Table 1). The extent of variability presented in (Table 2) in terms of range, mean, phenotypic coefficient of variability, genotypic coefficient of variability, heritability, genetic advance and genetic advance as percent of mean.

The values of PCV obtained for yield and its attributing characters ranged from (6.30) for days to $50 \%$ floweringto (17.23) for fodder yield. The values of GCV ranged from (2.75) for plant height to (7.54) for grain yield. Phenotypic coefficient of variability was higher than genotypic coefficient of variability for all the characters indicating that the interaction of genotypes with environment. Moderate PCV was observed for fodder yield followed by grain yield and plant height. These results were similar with the earlier reports of Yogeesh et al. (2015) ${ }^{[10]}$ for plant height in foxtail millet. Lower GCV was observed for all the yield attributing characters and low PCV was observed by number of productive tillers followed days to $50 \%$ flowering and days to maturity. The results were similar with the earlier reports of Yogeesh et al. (2015) for days to 50\% flowering in foxtail millet.

Heritability ranged from (6.11) for plant height to (95.74) for days to maturity. High heritability was recorded by days to maturity (95.74) followed by days to 50\% flowering (78.20). The results were similar with the earlier reports of Sreeja (2014) ${ }^{[9]}$. Genetic advance as percent of mean ranged from (1.40) for plant height to (10.15) for days to $50 \%$ flowering. High heritability coupled with moderate genetic advance as percent of mean was observed for days to $50 \%$ flowering indicating that these traits are under the influence of both additive and non-additive gene action and selection may be effective for this traits. Similarly grain recorded moderate heritability with moderate genetic advance as percent of mean indicating the role of additive and non-additive gene action. Correlation coefficients for different pairs of characters were given in (Table 3). Significant positive association of grain yield per plant was observed with days to $50 \%$ flowering, days to maturity and fodder yield. This suggests selecting for these characters would improve the grain yields in kodomillet. Days to $50 \%$ flowering exhibited significant positive association with days to maturity, fodder yield and grain yield. Days to maturity exhibited positive significant association with days to $50 \%$ flowering, fodder yield and grain yield. Fodder yield exhibited positive association with days to $50 \%$ flowering, days to maturity and grain yield. Plant height and number of productive tillers showed nonsignificant positive association with all the characters.

It is concluded that the variability present in the population is mainly used for varietal improvement of future breeding programmes. This study indicated that days to $50 \%$ flowering and grain yield were under the control of both additive and non-additive gene action. However, grain yield is mostly controlled by many genes with less effect while days to $50 \%$ flowering is controlled by fewer genes with greater effect, hence indirect selection of grain yield through days to $50 \%$ flowering may be rewarding.

Table 1: Analysis of variance of six characters for 18 genotypes in Kodomillet (Paspalumscrobiculatum L.)

\begin{tabular}{|c|c|c|c|c|c|c|c|c|}
\hline \multicolumn{9}{|c|}{ Mean sum of squares } \\
\hline S.no & Sources & Df & $\begin{array}{c}\text { Days to } 50 \% \\
\text { Flowering }\end{array}$ & $\begin{array}{l}\text { Plant height } \\
\text { (cm) }\end{array}$ & Days to Maturity & $\begin{array}{c}\text { Number of Productive } \\
\text { Tillers/Plant }\end{array}$ & $\begin{array}{c}\text { Grain Yield } \\
\text { (q/ha) }\end{array}$ & $\begin{array}{c}\text { Fodder Yield } \\
(\mathbf{q} / \mathbf{h a})\end{array}$ \\
\hline 1 & Treatments & 17 & $33.51^{\text {*** }}$ & 199.59 & $41.10^{* *}$ & 0.56 & $30.95^{* * *}$ & 91.61 \\
\hline 2 & Replication & 2 & 20.91 & 5.65 & 32.72 & 0.54 & 26.61 & 106.16 \\
\hline 3 & Error & 34 & 9.81 & 166.98 & 10.82 & 0.31 & 10.42 & 57.57 \\
\hline
\end{tabular}

Table 2: Estimates of genetic variability parameters of yield component attributes in Kodomillet (Paspalumscrobiculatum L.)

\begin{tabular}{|c|c|c|c|c|c|c|c|c|c|c|}
\hline S. No. & Characters & Mean & Maximum & Minimum & GCV & PCV & ECV & $\mathbf{H}^{2}$ & GA & GAM \\
\hline 1 & Days to $50 \%$ flowering & 57.41 & 64.00 & 51.33 & 5.57 & 6.30 & 2.94 & 78.20 & 5.82 & 10.15 \\
\hline 2 & Plant height $(\mathrm{cm})$ & 119.74 & 133.13 & 104.44 & 2.75 & 11.14 & 10.79 & 6.11 & 1.68 & 1.40 \\
\hline 3 & Days to maturity & 88.96 & 95.33 & 82.67 & 4.11 & 4.20 & 0.87 & 95.74 & 7.37 & 8.28 \\
\hline 4 & Number of productive tillers & 6.74 & 7.80 & 6.20 & 4.23 & 9.33 & 8.32 & 20.57 & 0.27 & 3.95 \\
\hline 5 & Grain yield (q/ha) & 34.72 & 42.43 & 30.70 & 7.54 & 11.97 & 9.30 & 39.64 & 3.39 & 9.77 \\
\hline 6 & Fodder yield (q/ha) & 48.17 & 59.13 & 40.54 & 6.99 & 17.23 & 15.75 & 16.46 & 2.82 & 5.84 \\
\hline
\end{tabular}


Table 3: Correlation coefficients between grain yield and its component characters in Kodo millet

\begin{tabular}{|c|c|c|c|c|c|c|}
\hline Character & $\begin{array}{c}\text { Days to 50\% } \\
\text { flowering }\end{array}$ & $\begin{array}{c}\text { Plant height } \\
\text { (cm) }\end{array}$ & $\begin{array}{c}\text { Days to } \\
\text { maturity }\end{array}$ & $\begin{array}{c}\text { Number of productive } \\
\text { tillers/ Plant }\end{array}$ & $\begin{array}{c}\text { Fodder yield } \\
(\mathbf{q} / \mathbf{h a})\end{array}$ & $\begin{array}{c}\text { Grain yield } \\
(\mathbf{q} / \mathbf{h a})\end{array}$ \\
\hline Days to 50\% flowering & 1.000 & 0.087 & $0.985^{* *}$ & 0.253 & $0.883^{* *}$ & $0.942^{* *}$ \\
\hline Plant height (cm) & & 1.000 & 0.114 & 0.076 & 0.064 & 0.124 \\
\hline Days to maturity & & & 1.000 & 0.308 & $0.858^{* *}$ & $0.936^{* *}$ \\
\hline Number of productive tillers/ Plant & & & & 1.000 & 0.399 & 0.237 \\
\hline Fodder yield (q/ha) & & & & & 1.000 & $0.865^{* *}$ \\
\hline Grain yield (q/ha) & & & & & 1.000 \\
\hline
\end{tabular}

\section{References}

1. Burton GW. Quantitative inheritance in grasses. Proc. 6th Int. Grassland Cong. 1952; 1:277-283.

2. Chandrasekara A, Shahidi F. Determination of antioxidant activity in free and hydrolyzed fractions of millet grains and characterization of their phenolic profiles by HPLC-DAD-ESIMS. J Funct. Foods. 2011; 3:144-158.

3. Hulse JM, Laing EM, Pearson OE. Sorghum and the Millets: their composition and nutritive value. Academic Press, New York, 1980.

4. Johnson HW, Robinson HF, Comstock RE. Estimation of genetic variability and environmental variability in soybean. Agronomy Journal. 1955; 47:314-318.

5. Lush JL. Intra-sire correlation and regression of offspring on dams as a method of estimating heritability of characters. In: Proc. of American Society of Animal Production. 1940; 33:293-301.

6. Padulosi S, Mal B, Bala Ravi S, Gowda J, Gowda KTK, Shanthakumar G et al. Food security and climate change: role of plant genetic resources of minor millets. Indian Journal of Plant Genetic Resources. 2009; 22:1-16.

7. Panse VG, Sukathme PV. Statistical method for agricultural workers. ICAR, New Delhi, 1967, 381.

8. Robinson HF, Comstock RE, Harvey PH. Estimates of heritability and the degree of dominance in corn (Zea mays). Agronomy Journal. 1949; 41:353-359.

9. Sreeja R. Characterization and selection of Kodo millet (Paspalums corniculate L.) genotypes with high culm strength to suit mechanical harvesting. Ph.D. Thesis, Tamil Nadu Agric. Univ., Coimbatore, India, 2014.

10. Yogeesh LN, Shankar KA, Prashant SM, Lokesh GY. Genetic Variation and Morphological Diversity in Foxtail millet. International Journal of Science and Environment. Technology. 2015; 4(6):1496-1502. 